
\title{
ОПЫТ РЕФОРМИРОВАНИЯ ТЕОЛОГИЧЕСКОГО ОБРАЗОВАНИЯ В РОССИИ В 1990-2000-Х ГГ.: НАПРАВЛЕНИЯ И ПЕРСПЕКТИВЫ ${ }^{1}$
}

\section{THE EXPERIENCE OF REFORMING THEOLOGICAL EDUCATION IN RUSSIA IN THE 1990-2000S: DIRECTIONS AND PROSPECTS}

\section{N. Grigoryeva \\ M. Simonova \\ S. Resnyanskiy}

Summary: The article, which continues the series of authors' publications on the history of theological education, examines the evolution of the secular and confessional systems of theological education in Russia over the past thirty years. Particular attention is paid to the tasks of the state and the church in this area and the choice of ways to solve them.

The stages of reforming domestic systems of theological education are determined and characterized. The assessments of the process and expected results of the reform of domestic systems of theological education are presented. The importance of church-state interaction in the development of the institutional, content and value foundations of theological education is emphasized.

The methodological basis of the research is made up of the principles of historicism, scientific objectivity, consistency and complexity, which make it possible to study the historical experience of the development of theological education, problems and achievements in this area.

The novelty of the research lies in the rethinking of the conceptual foundations of the historical experience of reforming theological education in Russia in the 1990-2000s.

Keywords: theological education, value bases, reforms.
Григорьева Наталья Анатольевна

Д.и.н., nрофесссор, ФГАОУ ВО «Российский университет

дружбы народов»

grigoryeva-na@rudn.ru

Симонова Мария Александровна

Д.и.н., nрофрессор, ФГАОУ ВО «Российский университет

дружбы народов»

simonova-ma@rudn.ru

Реснянский Сергей Иванович

Д.и.н., nрофессор, ФГАОУ ВО «Российский университет

дружбы народов»

resnyanskiy-si@rudn.ru

Аннотация: В статье, которая продолжает серию публикаций авторов по истории теологического образования, рассматривается эволюция светской и конфессиональной систем теологического образования в России за последние тридцать лет. Особое внимание уделено задачам государства и Русской Православной Церкви (РПЦ) в данной сфере и выбору путей их решения. Определены и охарактеризованы этапы реформирования отечественных систем теологического образования. Представлены оценки процесса и ожидаемых результатов реформы отечественных систем теологического образования. Подчёркивается важность церковно-государственного взаимодействия в развитии институциональных, содержательных и ценностных оснований теологического образования.

Методологическую базу исследования составляют принципы историзма, научной объективности, системности и комплексности, которые позволяют исследовать исторический опыт развития теологического образования, проблемы и достижения в данной сфере.

Новизна исследования заключается в переосмыслении концептуальных основ исторического опыта реформирования теологического образования в России в 1990-2000-х гг.

Ключевые слова: теологическое образование; ценностные основания; реформы.

Изучение отечественного опыта развития данных образовательных систем свидетельствует как о наличии дореволюционной традиции их реформирования в общей логике и взаимообусловленности, так и о советском императиве, согласно которому конфессиональная система теологического образования формировалась в условиях отсутствия светской системы.

На рубеже 1980-90-х гг. необходимость адекватного ответа государства и церкви на новые вызовы современности привели к масштабной реформе систем теологического образования в Российской Федерации. 
На первом этапе реформирования, границы которого целесообразно определить как руб.1980-90-х гг.сер.1990-х гг., были определены как институциональные, так и содержательные параметры обеих образовательных систем.

На Архиерейском Соборе Русской Православной Церкви (1989 г.) были обозначены институциональные аспекты данной реформы, включая перспективы для духовных семинарий в виде получения статуса церковных вузов, для академий - расширение их функций и полномочий как центров научно-богословской деятельности, включая работу по подготовке кадров, для духовных училищ- в части создания условий для формирования готовности их выпускников к эффективному социальному служению [1]. Кроме того, в этот период речь шла об изменении содержательных констант образования, что нашло отражение в трансформациях учебных планов духовных учреждений, в расширении спектра учебных дисциплин, включая патрологию, апологетику, историю философии и др. Параллельно открывались новые духовные учреждения.

В свою очередь, в реформе светской системы теологического образования важной вехой стало утверждение требований к обязательному минимуму содержания и уровню подготовки бакалавра по направлениям 520200 - "Теология" и 522400 - "Религиоведение" и выпускника по специальности 022200 - "Религиоведение" как действующих до введения государственного стандарта [8].

Таким образом, особенностью первого этапа реформы систем теологического образования являлась ее полинаправленность: для конфессиональной системы приоритетными были и институциональные, и содержательные изменения, для светской системы акцент был сделан на содержательно- технологическом векторе преобразований.

На втором этапе реформирования систем теологического образования (сер.1990-х гг.-нач. 2010-х гг.) профессиональным сообществом обсуждались различия не только в приоритетах планируемых изменений, но и их динамике.

Так, применительно к конфессиональной системе теологического образования цели, основные направления и темпы реформы образовательной системы были подтверждены решениями Архиерейского Собора 1994 года [7]. На основе новой Концепции высшего духовного образования Русской Православной Церкви [5], утвержденной на заседании Священного Синода РПЦ, активизировалась разработка соответствующих церковных образовательных стандартов подготовки специалистов в области православного богословия для духовных се- минарий и академий.

Кроме того, данный этап характеризуется созданием условий для формирования институциональных основ светской системы теологического образования посредством открытия в вузах соответствующих центров, кафедр, факультетов для подготовки теологов. В государственный классификатор образовательных направлений и специальностей было включено направление «Теология» [9] и был принят соответствующий стандарт, разработанный на поликонфессиональной основе, значительно повторявший как структурно, так и содержательно, образовательные стандарты, принятые в государственных вузах.

Качество и темпы реформирования системы конфессионального теологического образования были положительно оценены на Архиерейском соборе 2008 г., где также были намечены дальнейшие перспективы и механизмы ее преобразования в контексте оптимизации процесса подготовки квалифицированных кадров для Русской Православной Церкви, включая создание условий для получения духовными образовательными учреждениями государственной аккредитации.

В течение следующего года филиал аспирантуры Московской духовной академии при Отделе внешних церковных связей был преобразован в общецерковную аспирантуру, в дальнейшем - Общецерковную аспирантуру и докторантуру имени святых равноапостольных Кирилла и Мефодия для подготовки научных и преподавательских кадров высшей квалификации. Ее создание также было направлено на расширение спектра богословских (теологических) исследований. На очередном заседании Священного Синода 27 июля 2009 г. был утвержден Устав Общецерковной аспирантуры и докторантуры [12], после чего сформированы такие профили подготовки специалистов, как: литургика и церковные искусства, библеистика и патрология, внешние церковные связи и церковная история.

Оценки процесса и ожидаемых результатов реформы светской системы теологического образования были представлены в научном сообществе как диаметрально противоположные, объектами критики и обсуждения являлись вопросы возможности и необходимости преподавании теологии в светских вузах, легитимности светского теологического образования, проекты государственного образовательного стандарта по специальности «Теология», правовые, научные и этические аспекты реформы в целом.

Третий этап реформирования систем теологического образования (нач. 2010-х гг.- наст.время) характеризовался системными изменениями их содержательных, методических и институциональных оснований, при- 
влечением внешних экспертов для поиска, оценки и прогнозирования направлений дальнейших преобразований. Так, например, над созданием Образовательной концепции Русской Православной Церкви [10] работали не только члены Координационного совета по проведению реформы системы духовного образования под эгидой Учебного комитета РПЦ, но и представители международной консалтинговой компании "Monitor Group", специалисты Фонда просвещения «Мета» и др. [6].

С учетом приоритетов церкви и основных направлений государственной образовательной политики была сформирована трехуровневая система теологического образования, где на первом уровне реализуются программы бакалавриата, на втором- программы магистратуры, на третьем- программы аспирантуры. Длительность обучения в светских и духовных образовательных организациях составляла на первом уровне 4 года, на последующих, соответственно, 2 и 3 года. После обсуждения профессиональным сообществом проекты программ бакалавриата и магистратуры для духовных учебных заведений и положений об итоговых и научноквалификационных работах (диссертациях), об ученых званиях и штатных должностях были одобрены Священным Синодом в марте 2011 года [13].

В данном контексте применительно к конфессиональной системе теологического образования диплом бакалавра становился обязательным для священника, диплом магистра- для преподавателей богословских дисциплин и управленцев всех уровней для епархий и центральных церковных учреждений.

Отличительной особенностью данного этапа реформы является широкое обсуждение ее содержания и полученных результатов с привлечением широкой общественности и профессионального сообщества в форматах совещаний и конференций, а также апробация нескольких вариантов образовательных программ, что свидетельствовало об активном поиске эффективных механизмов достижения целей реформы систем теологического образования.

Каждый этап реформирования систем теологического образования сопровождался оценкой полученных результатов и рекомендациями прогностического характера. Так, например, в 2013 году на основе масштабной инспекции деятельности 36 духовных семинарий была дана оценка их потенциала и уровня его реализации в части соответствия качества подготовки обучающихся имеющемуся запросу. Из общего числа учреждений только 1/6 располагали необходимыми ресурсами для реализации магистерских программ, большинство ориентировались на соответствие уровню бакалавриата, некоторые оказались в ситуации возможного лишения «статуса самостоятельных высших духовных учебных заведений» [3]. Данные рекомендации обсуждались на заседании Священного Синода, где был актуализирован трехлетний период, в течении которого высшие духовные учреждения должны были скорректировать показатели своего развития в контексте проводимой реформы, училищам предлагалось сформировать планы оптимизации деятельности либо в статусе духовных семинарий в соответствии с установленными требованиями к качеству образования на основе Единого учебного плана [4], кадровым ресурсам и материально- техническому оснащению, либо в статусе центров подготовки миссионеров или катехизаторов для епархий. Очевидно, что проводимая реформа кардинально меняла существующие подходы к образовательному процессу в духовных учреждениях.

Во многом темпы и логика процесса реформирования системы конфессионального теологического образования были детерминированы острой недостаточностью высококвалифицированных специалистов для реализации программ магистратуры и аспирантуры. В связи с этим с 2010 г. Общецерковной аспирантурой были подписаны соответствующие соглашения с российскими и зарубежными образовательными организациями высшего образования, включая Высшую школу экономики, Московскую государственную консерваторию, Московский государственный институт международных отношений, Российскую академию народного хозяйства и государственной службы при Президенте РФ и др. [14; $11 ; 2 ; 15 ; 16]$, ресурсы которых могли быть привлечены для достижения целей реформы конфессиональной и светской систем теологического образования.

С 2015 года, когда теология была внесена в номенклатуру научных работников, был разработан и утвержден паспорт научной специальности «Теология», начался системный процесс подготовки кадров высшей квалификации для обеспечения потребностей обеих систем теологического образования. В 2021 году теология была внесена в новый перечень научных специальностей комплексно по трем направлениям: "Теоретическая теология", "Историческая теология (по исследовательскому направлению: православие, ислам, иудаизм)" и "Практическая теология" [19], что свидетельствовало об успешности реформирования систем теологического образования. Результаты реформы в контексте динамики приоритетов государственно- церковного взаимодействия стали предметом традиционного обсуждения на Архиерейских Соборах РПЦ, конференциях и семинарах- совещаниях $[17 ; 18 ; 20]$.

Отметим, что несмотря на сформированную за время проведения реформ необходимую законодательную базу, развитие конфессиональной и светской систем теологического образования в отечественной практике развивается в условиях целого комплекса противоре- 
чий:

- между необходимостью формирования единого теологического образовательного пространства и недостаточной готовностью профессионального сообщества к внедрению необходимых изменений;

- между теологическим образованием как ресурсом подготовки кадров для органов государственного управления в сфере межрелигиозных отношений, подготовки преподавателей, исследователей и степенью его реализации в массовой практике;

- между национальными традициями в сфере теологического образования и новыми задачами государственной политики, а также запросами современного рынка труда;

- между концептуальными основаниями реформирования систем теологического образования и иерархией приоритетов в деятельности светских и духовных образовательных учреждений;

- между целями и задачами государства и церкви по развитию теологического образования и фактором ведомственной несогласованности.

Направленность и динамика разрешения данных противоречий во многом определяет степень выраженности современных тенденций развития систем теологического образования в Российской Федерации.

\section{ЛИТЕРАТУРА}

1. Верейский (Решетников) Евгений(архиеп.) Реформа духовного образования Русской Православной Церкви: актуальные задачи, проблемы, перспективы// http://www.pravoslavie.ru/437.html.

2. В РАНХиГС и Общецерковной аспирантуре и докторантуре РПЦ создан Межвузовский научно-образовательный центр «Религия и общество»/ https:// www.ranepa.ru/sobytiya/novosti.

3. Доклад Патриарха Московского и всея Руси Кирилла на Архиерейском Соборе 2 февраля 2013 года// Журнал Московской Патриархии. 2013. №3. С.12-45.

4. Единый учебный план введен для всех семинарий Русской Православной Церкви (2015 г.)// http://www.orthedu.ru/obraz/13638.html.

5. Из постановлений Священного Синода от 21 августа 2007 г. (журнал №71)// https://mosmit.ru/library/vedomosti/27/349/.

6. Координационный совет обсудил планы внедрения стратегических инициатив по переходу учебных заведений РПЦ на Болонскую систему (17.04.2012)// https://www.donorsforum.ru/reports/.

7. О задачах Церкви в области богословского образования// http://www.patriarchia.ru/db/ document/400445/.

8. $0 б$ утверждении государственного образовательного стандарта в части классификатора направлений и специальностей высшего профессионального образования: приказ Государственного Комитета Российской Федерации по высшему образованию от 5 марта 1994 г. N 180// https://normativ.kontur.ru/ document?moduleld $=1 \&$ documentld $=48420$.

9. 06 утверждении государственных образовательных стандартов высшего профессионального образования: приказ Минобразования РФ от 2 марта 2000 года №686// https://base.garant.ru/.

10. Образовательная концепция Русской православной Церкви// http://oroik-bryansk.cerkov.ru/obrazovatelnaya-koncepciya-russkoj-pravoslavnoj-cerkvi/.

11. Общецерковная аспирантура и МГИМ0 подписали соглашение о сотрудничестве в учебных программах (24 ОКТЯБРЯ, 2013 ГОДА)// https://www.pravmir. ru/.

12. Определения Священного Синода// Журнал Московской Патриархии. 2009. № 9. С.6-15.

13. Определения Священного Синода// Журнал Московской Патриархии. 2011. №5. С.6-13.

14. Подписано соглашение о сотрудничестве между Общецерковной аспирантурой и докторантурой и Московской государственной консерваторией (24 ноября 2017 года)// http://www.patriarchia.ru/db/text/5070698.html.

15. Подписан договор о сотрудничестве Общецерковной аспирантуры и докторантуры со Свободным университетом Амстердама (22 сентября 2011 года)// https://mospat.ru/ru/news/55186/.

16. Подписано соглашение о сотрудничестве между Общецерковной аспирантурой и докторантурой и Высшей школой экономики// https://ruskline.ru/ news_rl/2012/02/11/.

17. Представители более 100 образовательных организаций высшей школы обсудили развитие теологического образования на Всероссийском совещаниисеминаре в НИЯУ «МИФИ» (28.10.2020)// https://nota-theology.ru/news/202010281998.

18. Совещание о развитии теологического образования прошло в Москве (30.10.2020)/ https://na.ria.ru/20201030/nota-1583775128.html.

19. Теология вошла в качестве отрасли знания в новую номенклатуру научных специальностей $Р Ф / / \mathrm{http}: / /$ www.patriarchia.ru/db/text/5796017.html.

20. III Международная научная конференция «Теология в современном научно-образовательном пространстве: религия, культура, просвещение» (2019г.)// http://www.patriarchia.ru/. 